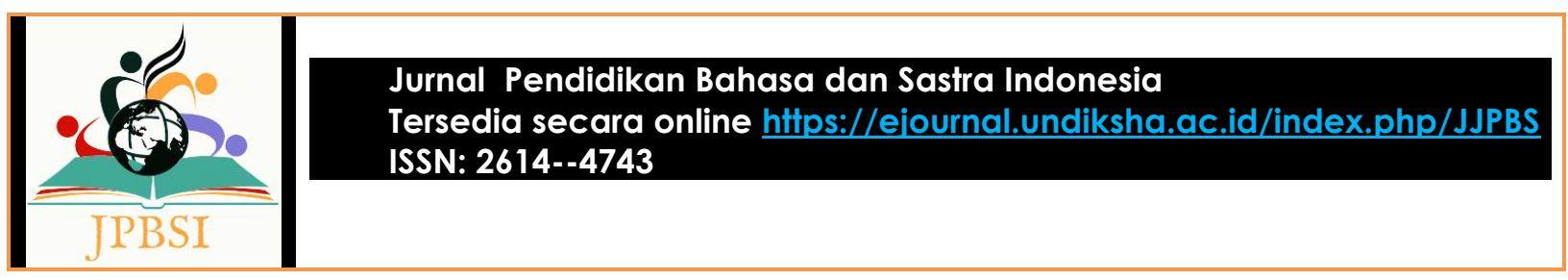

\title{
TINDAK TUTUR ILOKUSI DALAM DIALOG TOKOH DILAN PADA FILM DILAN 1990 KARYA PIDI BAIQ DAN FAJAR BUSTOMI
}

\author{
Siti Nurhilma Maulidia Rohmah ${ }^{1}$, Asep Firdaus ${ }^{2}$, David Setiadi ${ }^{3}$ \\ ${ }_{1,2,3}$ Program Studi Pendidikan Bahasa Indonesia, Universitas Muhammadiyah Sukabumi \\ Sukabumi, Jawa Barat, Indonesia
}

Surel: hilmamaulidia18@ummi.ac.id ${ }^{1}$,asepfirdaus@ummi.ac.id²,david156@ummi.ac.id ${ }^{3}$

\begin{tabular}{|c|c|}
\hline \multicolumn{2}{|r|}{ Abstrak } \\
\hline $\begin{array}{l}\text { Kata Kunci: Dialog; } \\
\text { Film; Tindak Tutur. } \\
\text { Pidi Baiq, Fajar } \\
\text { Bustomi }\end{array}$ & $\begin{array}{l}\text { Penelitian ini dilatarbelakangi oleh adanya tindak tutur ilokusi dalam dialog tokoh } \\
\text { Dilan pada film Dilan } 1990 \text { karya Pidi Baiq dan Fajar Bustomi. Penelitian ini } \\
\text { bertujuan untuk mendeskripsikan jenis-jenis tindak tutur ilokusi dan fungsi tindak } \\
\text { tutur ilokusi dalam dialog Dilam pada film Dilan } 1990 \text { karya Pidi Baiq dan Fajar } \\
\text { Bustomi. Metode yang digunakan dalam penelitian ini adalah metode deskriptif } \\
\text { kualitatif. Sumber data penelitian ini adalah film Dilan } 1990 \text { yang dirilis pada tahun } \\
\text { 2018. Seluruh tuturan ilokusi yang terdapat dalam dialog Dilan pada film Dilan } 1990 \\
\text { merupakan objek dalam penelitian ini. Pengumpulan data dilakukan dengan metode } \\
\text { simak dan transkripsi. Komponen tutur SPEAKING turut digunakan untuk } \\
\text { menentukan konteks data. Hasil penelitian ini menunjukkan bahwa ditemukan lima } \\
\text { jenis tindak tutur ilokusi dalam dialog tokoh Dilan pada film Dilan } 1990 \text { yaitu tindak } \\
\text { tutur ilokusi asertif, tindak tutur direktif, tindak tutur komisif, tindak tutur ekspresif } \\
\text { dan tindak tutur deklaratif. }\end{array}$ \\
\hline \multicolumn{2}{|r|}{ Abstract } \\
\hline $\begin{array}{l}\text { Keywords: Dialogue; } \\
\text { Film; Speech Act; Pidi } \\
\text { Baiq; Fajar Bustomi }\end{array}$ & $\begin{array}{l}\text { This research is motivated by the existence of illocutionary speech acts in the } \\
\text { dialogue of the character Dilan in the Dilan } 1990 \text { film by Pidi Baiq and Fajar } \\
\text { Bustomi. This study aims to describe the types of illocutionary speech acts and the } \\
\text { function of illocutionary speech acts in the Dilam dialogue in the Dilan } 1990 \text { film by } \\
\text { Pidi Baiq and Fajar Bustomi. The method used in this study is a qualitative } \\
\text { descriptive method. The data source for this research is the Dilan } 1990 \text { film which } \\
\text { was released in 2018. All illocutionary utterances contained in Dilan's dialogue in } \\
\text { the Dilan } 1990 \text { film are the objects of this research. Data collection was done by } \\
\text { listening and transcription methods. The speech component of SPEAKING is also } \\
\text { used to determine the context of the data. The results of this study indicate that there } \\
\text { are five types of illocutionary speech acts in Dilan's dialogue in the film Dilan 1990, } \\
\text { namely assertive illocutionary speech acts, directive speech acts, commissive speech } \\
\text { acts, expressive speech acts and declarative speech acts. }\end{array}$ \\
\hline $\begin{array}{l}\text { Diterima/direview/ } \\
\text { dipublikasi }\end{array}$ & 29 Juli 2021/ 30 Juli 2021/ 30 September 2021 \\
\hline
\end{tabular}

\section{PENDAHULUAN}

Bahasa digunakan oleh masyarakat sebagai alat berkomunikasi untuk menyampaikan suatu hal. Karena pada dasarnya keberadaan bahasa tidak dapat dipisahkan dari kehidupan manusia, terutama dalam kehidupan bermasyarakat yang menuntut manusia tersebut berhubungan dan bekerja sama dengan sesamanya, sehingga manusia memerlukan alat yang disebut Bahasa. Menurut Khairina (2017), kegiatan berkomunikasi dapat terlihat dalam bentuk sebuah kegiatan bertutur yang selalu hadir dalam kehidupan bermasyarakat, baik pada saat bersama teman, anggota keluarga, maupun bersama dengan orang lain. Suatu tuturan pasti mempunyai maksud atau arti serta faktor yang melatarbelakangi penutur dalam menyampaikan tuturannya kepada mitra tutur. Oleh karena itu, sangat diperlukan pengetahuan, pemahaman, serta pengalaman dalam komunikasi berbahasa (Purba, 2011). 


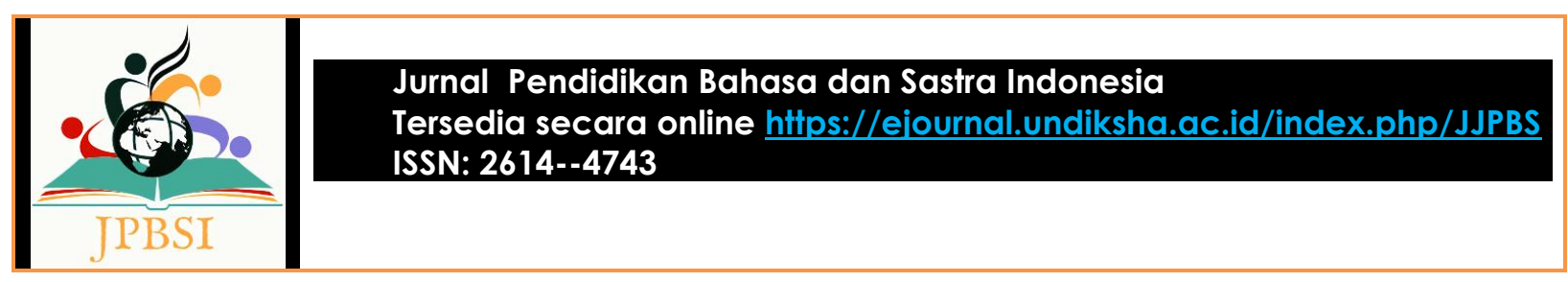

Tindak tutur bisa diartikan suatu tindakan yang ditampilkan lewat tuturan. Seperti ucapan permintaan maaf, pujian, janji, dan permohonan. Dibalik suatu tuturan terdapat fungsi bahasa yang tercermin dalam maksud tuturan tersebut. Suryanti (2020) berpendapat bahwa tindak tutur merupakan gejala individual yang bersifat psikologis dan keberlangsungan ditentukan oleh kemampuan bahasa dari penutur dalam menghadapi situasi tertentu. Menurut Austin (dalam Tarigan, 2015) ada tiga jenis tindak tutur yaitu, tindak tutur lokusi, 2) tindak tutur ilokusi, 3) tindak tutur perlokusi. Tindak tutur lokusi, melakukan tindakan untuk mengatakan sesuatu. Tindak tutur ilokusi, melakukan sesuatu tindakan dalam mengatakan sesuatu. Tindak tutur perlokusi, melakukan sesuatu tindakan dengan mengatakan sesuatu.

Moore sebagaimana dikatakan Rusminto (2015) menyatakan bahwa tindak ilokusi merupakan tindak tutur yang sebenarnya atau yang nyata diperformansikan oleh tuturan, seperti janji, sambutan, dan peringatan. Tindakan ini selain untuk mengucapkan sesuatu tetapi juga digunakan untuk melakukan sesuatu. Sedangkan menurut Agustiani (2019) mengemukakan bahwa tindak tutur ini mengaitkan apa yang dilakukan pembicara dengan perbuatan dalam hubungan dengan mengatakan sesuatu. Selanjutnya Leech (dalam Tarigan 2015) menjelaskan tindak tutur ilokusi dibedakan menjadi lima kategori, yaitu: tindak tutur verba asertif menyatakan, menuntut, mengeluh, mengakui, menunjukkan, melaporkan, memberi tahu, memberikan, menegaskan, mengemukakan pendapat, menduga, mendesak, dan menyatakan, tindak tutur verba direktif meminta, mengemis, menawar, memerintahkan, memerlukan, mengajak, melarang, menasehati, menganjurkan, memohonkan, tindak tutur verba komisif berjanji, bersumpah, mengancam, menyatakan kesangupan, dan menawarkan, tindak tutur verba ekspresif memuji, mengucapkan selamat, meminta maaf, mengucapkan terima kasih, mengampuni, dan menaruh simpati, tindak tutur verba deklaratif mengesahkan, membatalkan, melarang, mengizinkan, mengampuni, dan mengabulkan.

Selain dari komunikasi masyarakat, tindak tutur juga dapat ditemukan dalam sebuah film. Film merupakan satu bentuk situasi artifisial yang kemunculannya diinspirasi dari kehidupan sosial yang berkembang pada masanya. Menurut Widyawati (2019), film bisa berperan sebagai komunikasi bahasa karena tidak lepas dari percakapan atau aspek komunikasi. Kemudian film bisa diartikan bentuk komunikasi antara pembuat dengan penonton. Melalui gambar-gambar yang disajikan, film mengungkapkan maksudnya, menyampaikan pesan kepada penonton (Setyanto, 2015). Hal inilah yang menjadikan film dapat dijadikan sebagai media penyampaian pesan yang efektif bagi para penonton. Kemudian hal inipun yang membuat film layak dikaji lebih lanjut pada kajian pragmatik, khususnya tindak tutur ilokusi.

Pragmatik sebagai sebuah kajian dalam menelisik makna yang dikaitkan dengan konteks sangat relevan digunakan dalam membedah sebuah tuturan. Film Dilan 1990 karya Pidi Baiq dan Fajar Bustomi dipilih sebagai objek penelitian karena pada dasarnya tema film ini memiliki nuansa yang dirasa sering dialami dalam kehidupan sehari-hari, tidak hanya itu film ini juga memiliki kata-kata indah yang puitis dalam dialog-dialognya. Adapun tema yang diangkat dalam film ini tentang kisah cinta remaja di masa lalu yang penuh kejutan karena sosok Milea dipertemukan dengan laki-laki yang sering disebut panglima tempur dari Bandung hingga dipenuhi konflik. Film ini juga dibuatkan beberapa film lanjutan dari kisahnya di antaranya Dilan 1990, Dilan 1991, dan Milea Suara dari Dilan. Film ini banyak mengingatkan kita pada masa 1990-an. Dalam penelitian ini, penulis mengambil tuturan yang terjadi pada tokoh Dilan dalam dialog film Dilan 1990 karya Pidi Baiq dan Fajar Bustomi.

Fokus penelitian ini yaitu pada tindak tutur ilokusi karena kelebihan tindak tutur ilokusi yang mempunyai fungsi atau daya tuturan tertentu. Selain itu juga tindak tutur ilokusi selalu kita temukan dalam kegiatan sehari-hari baik secara sadar maupun tidak sadar, dan jika dihubungkan dengan film Dilan 1990 terlihat peran ilokusi karena film tersebut terdapat banyak tuturan ilokusi yang diujarkan oleh tokoh di dalamnya. Selanjutnya akan diparkan jenis-jenis tindak tutur ilokusi yang terdapat dalam 


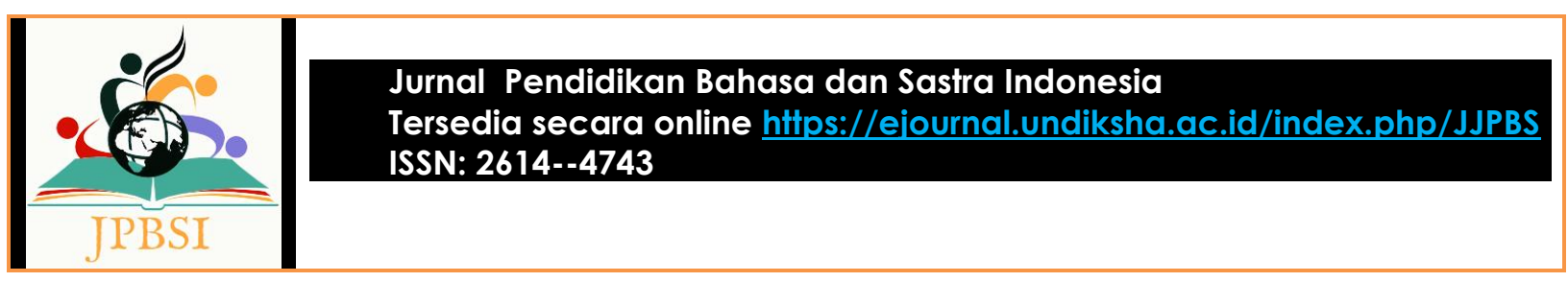

dialog tokoh Dilan pada film Dilan 1990 karya Pidi Baiq dan Fajar Bustomi, dan juga fungsi tindak tutur ilokusi dalam dialog tokoh Dilan pada film Dilan 1990 karya Pidi Baiq dan Fajar Bustomi.

\section{METODE PENELITIAN}

Penelitian ini menggunakan metode penelitian kualitatif untuk menunjang keberlangsungan penelitian. Sugiyono (2018) menjelaskan bahwa metode penelitian kualitatif dinamakan sebagai metode baru, karena popularitasnya belum lama, dinamakan postpositivistik karena berlandaskan pada filsafat postpositivisme. Dalam penelitian kualitatif instrumennya adalah orang atau human instrument, yaitu peneliti itu sendiri. Adapun desain penelitian yang digunakan adalah deskriptif kualitatif yang berupa penjelasan dan uraian sesuai dengan masalah yang diteliti. Langkah utamanya yaitu menganalisis secara langsung data penelitian yang berupa jenis tindak tutur ilokusi dalam penggolongan Searle yang terdapat dalam dialog tokoh Dilan pada film Dilan 1990 karya Pidi Baiq dan Fajar Bustomi. Kemudian dilakukan dengan cara mengamati dan memahami objek penelitian tersebut berdasarkan kajian pragmatik yaitu dengan menjelaskan tentang tindak tutur ilokusi. Penelitian deskriptif ini digunakan berdasarkan data transkripsi yang terdapat dalam dialog tokoh yang dijadikan kata-kata atau kalimat tertulis untuk di tafsirkan kepada konteks penggunaannya.

Penelitian ini bertujuan untuk dapat memahami fenomena kebahasaan tentang tindak tutur ilokusi yang terdapat dalam film Dilan 1990 yang pernah ramai di perbincangkan masyarakat. Sumber data dalam penelitian ini adalah Film Dilan 1990 berupa dialog yang sudah ditulis ulang atau disalin ke dalam bentuk tulisan oleh penulis. Setelah itu, dikembangkan instrumen penelitian secara singkat. Seperti yang diungkapkan Sutedi (2011) bahwa instrumen penelitian yaitu alat yang digunakan untuk mengumpulkan atau menyediakan berbagai data yang diperlukan dalam kegiatan penelitian. Instrumen yang digunakan dalam penelitian ini ialah peneliti sendiri karena penulis bertindak sebagai yang mengumpulkan data dengan membuat tabel klasifikasi data, menganalisis data untuk dimasukan kedalam berbagai kategori, menafsirkan data dan yang melaporkan hasil dari penelitiannya.

\section{HASIL DAN PEMBAHASAN}

Hasil penelitian ini berupa deskripsi jenis tindak tutur ilokusi yang terdapat dalam dialog tokoh Dilan pada film Dilan 1990. Tindak tutur ilokusi yang terdapat dalam dialog tokoh Dilan pada film Dilan 1990, yaitu tindak tutur asertif, direktif, komisif, deklaratif dan ekspresif. Jenis tinda tutur asertif dalam dialog tokoh Dilan pada film Dilan 1990 sejumlah 32 data, tindak tutur direktif sejumlah 33 data, tindak tutur komisif terdapat 12 data, tindak tutur deklaratif terdapat 1 data, dan tindak tutur ekspresif terdapat 20 data. Keseluruhan data yang mengandung jenis tindak tutur ilokusi dalam dialog tokoh Dilan pada Film Dilan 1990 sebanyak 98 data. Hal ini dapat dilihat secara rinci pada tabel berikut.

Tabel 01. Jenis Tindak Tutur Ilokusi dalam dialog tokoh Dilan pada film Dilan 1990.

\begin{tabular}{|c|l|l|c|}
\hline No & \multicolumn{1}{|c|}{ Jenis Tindak Tutur Ilokusi } & \multicolumn{1}{|c|}{ Tuturan } & Jumlah \\
\hline 1 & Tindak tutur direktif & Memerintah, menyarankan, memohon, bertanya. & 33 \\
\hline 2 & Tindak tutur asertif & Menyatakan. melaporkan, menegaskan. & 32 \\
\hline 3 & Tindak tutur ekspresif & $\begin{array}{l}\text { Ucapan selamat, terima kasih, mengkritik, } \\
\text { mengeluh, meminta maaf. menyanjung }\end{array}$ & 20 \\
\hline 4 & Tindak tutur komisif & Menjanjikan, menawarkan. & 12 \\
\hline 5 & Tindak tutur deklaratif & Membuat keputusan & 1 \\
\hline \multicolumn{2}{|l|}{ Jumlah Keseluruhan } & 98 \\
\hline
\end{tabular}

Berdasarkan Tabel 01. di atas menunjukkan bahwa jenis tindak tutur asertif dan direktif paling sering digunakan dalam dialog tokoh Dilan pada film Dilan 1990. Hal ini dapat dilihat dari jumlah data yang terdapat pada jenis tindak tutur direktif sebanyak 33 data dari 98 data yang ada. Kemudian menandakan bahwa tokoh Dilan lebih sering mengharapkan suatu tindakan dari mitra tutur misalnya seperti memerintah, memohon, menyarankan, dan bertanya. Data ini diperlukan untuk mengetahui 


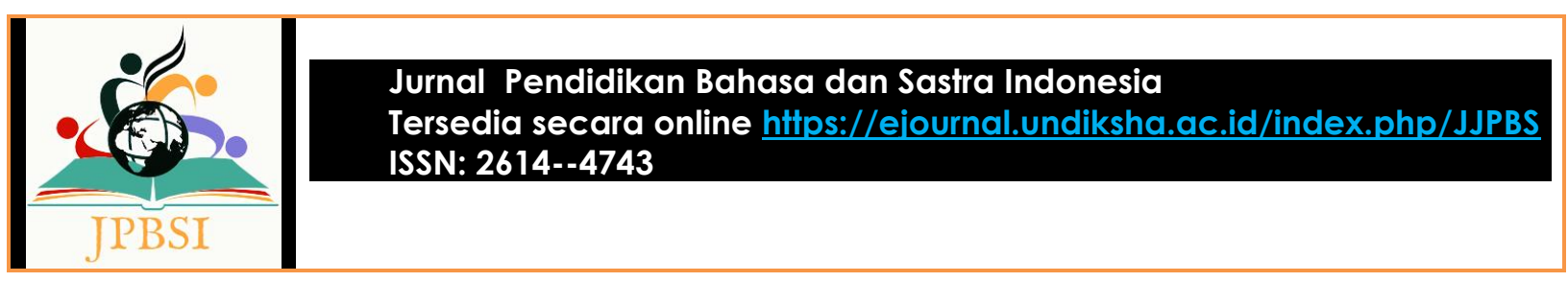

tuturan yang banyak dipakai oleh tokoh Dilan. Dari hasil temuan ini selaras dengan yang dijelaskan Kusumaningsih, di mana banyak ditemukan tuturan direktif dalam penelitiannya. Tuturan direktif banyak ditemukan dalam kehidupan sehari-hari, karena faktanya kita membutuhkan bantuan orang lain seperti meminta seseorang mengambil sesuatu atau melakukan lainnya (Kusumaningsih, 2016). Selanjutnya akan dipaparkan pembahasan dari hasil penelitian berikut.

\section{Jenis Tindak Tutur Ilokusi}

Jenis tindak tutur ilokusi yang ditemukan dalam penelitian ini terbagi menjadi lima jenis, yaitu tindak tutur asertif, direktif, komisif, deklaratif dan ekspresif. Berikut akan dipaparkan secara berurutan sesuai jenis tindak tutur ilokusi yang terdapat dalam tuturan tokoh Dilan pada film Dilan 1990.

a. Tindak Tutur Asertif

Pada ilokusi ini, penutur terikat kebenaran tuturan yang diutarakan. Adapun yang termasuk dalam jenis tindak tutur asertif dalam tuturan tokoh Dilan pada film Dilan 1990 yaitu menyatakan, melaporkan, menegaskan. Sebagaimana terlihat pada dialog di bawah ini.

1) Menyatakan

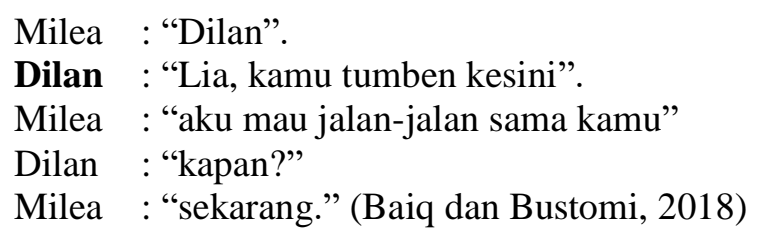

Tuturan (1) di atas merupakan dialog antara Dilan dan Milea. Tuturan tersebut terjadi saat Milea menghampiri Dilan yang sedang berada di warung Bi Eem. Pada tuturan tersebut, Dilan menyatakan keanehannya karena Milea datang ke tempat tongkrongan. Tuturan Dilan, yaitu "Lia, tumben kamu kesini" terjadi setelah Milea menyapa Dilan. Tuturan tersebut terjadi pada menit 72.53-73.04.

Berdasarkan data tersebut, dapat diketahui bahwa tuturan Dilan dalam kutipan dialog di atas merupakan jenis tindak tutur asertif menyatakan. Tuturan tersebut bermaksud menyatakan kebenaran tentang Milea yang tiba-tiba datang ke warung Bi Eem yang tidak seperti biasanya. Namun, maksud dari tuturan Dilan bukan hanya sekedar menyatakan suatu hal tetapi juga ingin mengetahui maksud kedatangan Milea. Tindak tutur yang menunjukkan asertif ini diketahui dari tuturan tokoh Dilan yang menyatakan pendapat untuk tujuan atau maksud tertentu.

2) Melaporkan

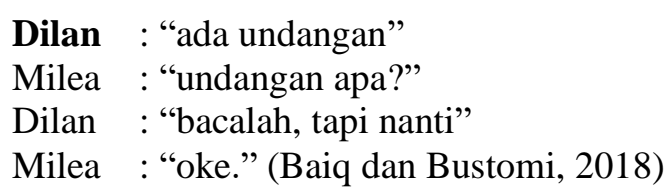

Tuturan (2) di atas merupakan dialog antara Dilan dan Milea. Tuturan tersebut terjadi di rumah Milea pada saat siang hari ketika libur sekolah. Pada tuturan tersebut, Dilan melaporkan untuk memberitahu sebuah informasi kepada Milea bahwa ada surat undangan yang ia bawa sendiri untuk diberikan kepada Milea. Tuturan Dilan, yaitu 'ada undangan' terjadi setelah Milea membukakan pintu rumah dan tanpa lama bicara, Dilan langsung memberikan informasi tersebut. Tuturan tersebut terjadi pada menit 03.38-03.45

Berdasarkan data tersebut, dapat diketahui bahwa tuturan Dilan dalam kutipan dialog di atas merupakan jenis tindak tutur asertif (melaporkan). Tuturan tersebut bermaksud memberikan suatu informasi kebenaran tentang adanya undangan yang ia bawa untuk Milea. Tuturan Milea "oke" di akhir 


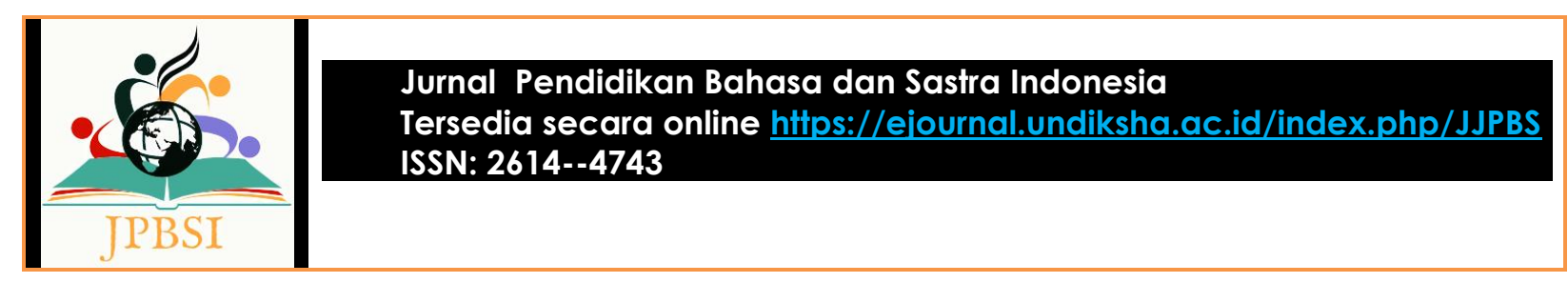

pembicaraan untuk membaca undangan tersebut menandakan bahwa Milea percaya bahwa yang dibawa Dilan adalah undangan untuknya. Namun, maksud dari tuturan Dilan bukan hanya sekedar melaporkan sesuatu tetapi juga memberikan surat yang harus Milea baca. Tindak tutur yang menunjukkan asertif ini diketahui dari tuturan tokoh Dilan yang melaporkan sesuatu untuk tujuan atau maksud tertentu.

3) Menegaskan

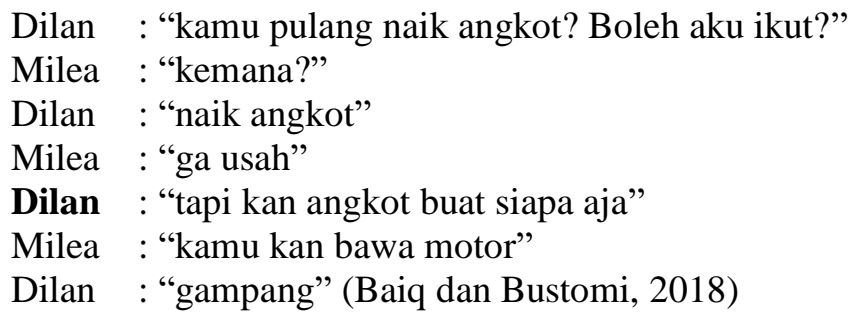

Tuturan (3) di atas merupakan dialog antara Dilan dan Milea. Tuturan tersebut terjadi di gerbang sekolah. Pada tuturan tersebut, Dilan memberi penjelasan bahwa angkot untuk siapa saja karena awalnya Milea tidak memperbolehkan Dilan naik angkot bersamanya. Tuturan Dilan, yaitu "tapi kan angkot buat siapa aja" terjadi setelah Dilan meminta pulang bersama dengan Milea. Tuturan tersebut terjadi pada menit 06.58-07.06.

Berdasarkan data tersebut, dapat diketahui bahwa tuturan Dilan dalam kutipan dialog di atas merupakan jenis tindak tutur asertif (menegaskan). Tuturan tersebut bermaksud memberikan penjelasan bahwa angkot itu untuk siapa saja tidak ada larangan. Maksud lain dari tuturan ini adalah Dilan bersikeras untuk memberikan penjelasan agar bisa pulang bersama dengan Milea. Tindak tutur yang menunjukkan asertif (menegaskan) ini diketahui dari tuturan tokoh Dilan yang memberi penegasan untuk tujuan atau maksud tertentu.

\section{b. Tindak Tutur Direktif}

Pada ilokusi ini, penutur mengharapkan suatu tindakan dari mitra tutur yang diinginkan oleh penutur. Adapun yang termasuk dalam jenis tindak tutur direktif dalam tuturan tokoh Dilan pada film Dilan 1990 yaitu memerintah, menyarankan, memohon dan bertanya. Sebagaimana terlihat pada dialog di bawah ini.

1) Memerintah

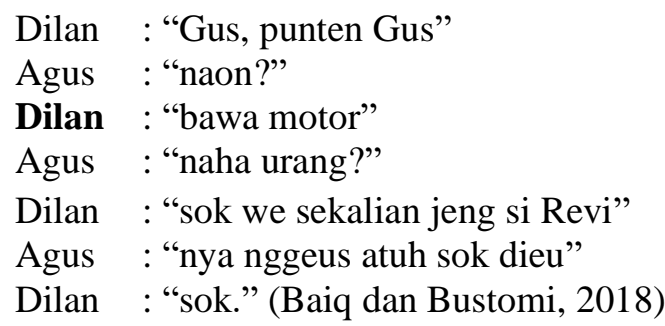

Tuturan (4) di atas merupakan dialog antara Dilan dan Agus. Tuturan tersebut terjadi di sekolah saat pagi hari. Pada tuturan tersebut, Dilan meminta Agus untuk membawakan motornya. Tuturan Dilan yaitu, "bawa motor" terjadi setelah Dilan mendekati Milea untuk sekedar mengobrol. Tuturan tersebut terjadi pada menit 47.11-47.16.

Berdasarkan data tersebut, dapat diketahui bahwa tuturan Dilan dalam kutipan dialog di atas merupakan jenis tindak tutur direktif (memerintah). Hal ini dilihat pada tuturan Dilan yang meminta suatu hal yang harus dilakukan Agus yaitu membawakan motor Dilan. Maksud lain dari tuturan ini adalah Dilan ingin jalan menemani Milea sampai ke kelas sambil mengobrol sehingga memerintah 


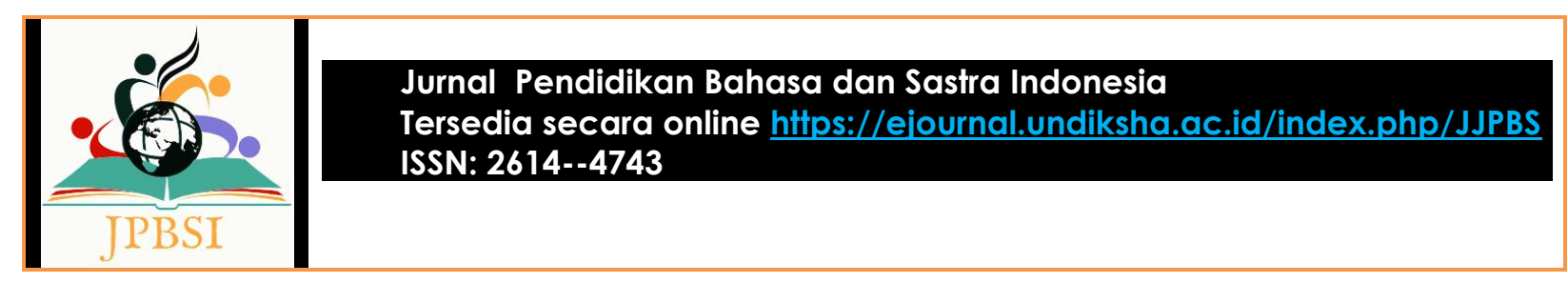

Agus membawakan motornya. Tindak tutur yang menunjukkan direktif (memerintah) ini diketahui dari tuturan tokoh Dilan yang meminta suatu hal yang bersifat menyuruh untuk tujuan atau maksud tertentu.

2) Menyarankan

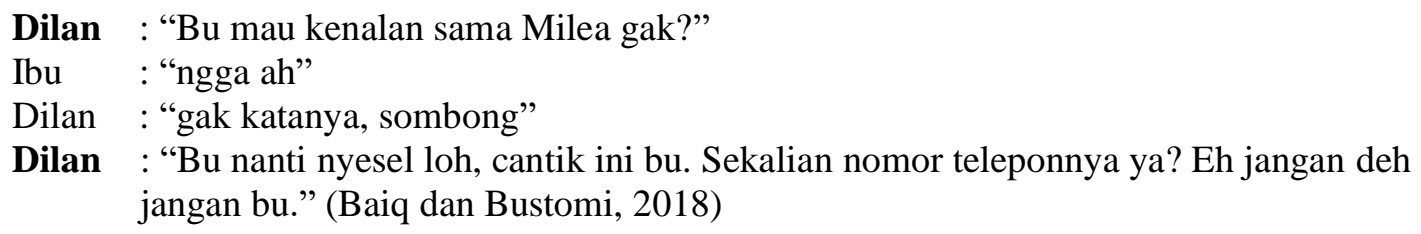

Tuturan (5) di atas merupakan dialog antara Dilan dan Ibu-ibu yang sedang mengantre di telepon umum saat siang hari. Pada tuturan tersebut, Dilan menyarankan kepada seorang ibu yang sedang mengantre telepon umum untuk berkenalan dengan Milea. Tuturan Dilan yaitu, "Bu mau kenalan sama Milea gak?" dilanjut "Bu nanti nyesel loh, cantik ini bu. Sekalian nomor teleponnya ya?" terjadi setelah Dilan dan Milea mengobrol di saluran telepon. Tuturan tersebut terjadi pada menit 44.4844.59 .

Berdasarkan data tersebut, dapat diketahui bahwa tuturan Dilan dalam kutipan dialog di atas merupakan jenis tindak tutur direktif (menyarankan). Hal ini dilihat pada tuturan Dilan yang menyarankan suatu hal kepada ibu-ibu yang sedang mengantre untuk berkenalan dengan Milea. Maksud lain dari tuturan ini adalah Dilan membuat gurauan agar Milea senang dan obrolan menjadi asyik. Tindak tutur yang menunjukkan direktif (menyarankan) ini diketahui dari tuturan tokoh Dilan yang memberikan usul seperti anjuran untuk tujuan atau maksud tertentu.

3) Memohon

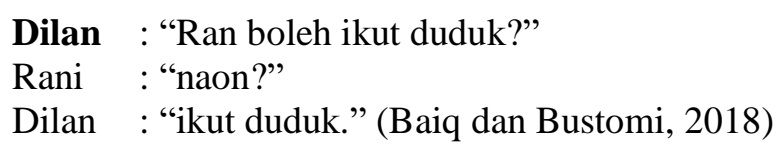

Tuturan (6) di atas merupakan dialog antara Dilan dan Rani. Tuturan tersebut terjadi di sekolah saat siang hari. Pada tuturan tersebut, Dilan meminta dengan sungguh agar bisa duduk di bangku Rani yang satu jajar dengan Milea. Tuturan Dilan yaitu, "Ran boleh ikut duduk?" terjadi setelah Dilan mendatangi kelas Milea. Tuturan tersebut terjadi pada menit 12.10-12.13.

Berdasarkan data tersebut, dapat diketahui bahwa tuturan Dilan dalam kutipan dialog di atas merupakan jenis tindak tutur direktif (memohon). Hal ini dilihat pada tuturan Dilan yang meminta suatu hal dengan sungguh-sungguh yaitu ingin duduk dekat Milea. Maksud lain dari tuturan ini adalah agar Rani bisa pindah ke tempat lain karena Dilan ingin mengobrol dengan Milea. Tindak tutur yang menunjukkan direktif (memohon) ini diketahui dari tuturan tokoh Dilan yang meminta dengan hormat untuk tujuan atau maksud tertentu.

4) Menanyakan

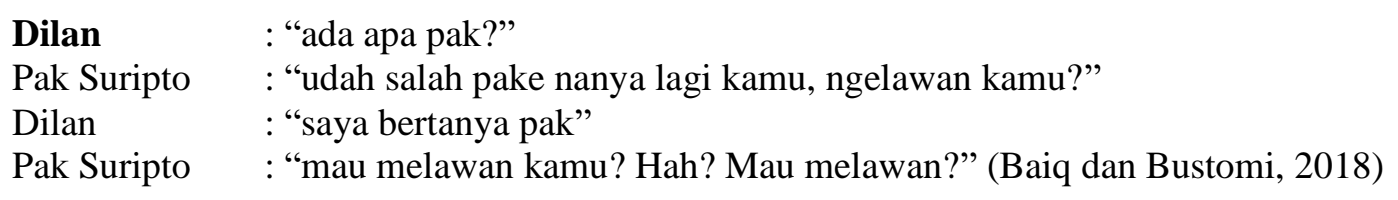

Tuturan (7) di atas merupakan dialog antara Dilan dan Pak Suripto. Tuturan tersebut terjadi di sekolah saat pelaksanaan upacara pagi hari. Pada tuturan tersebut, Dilan meminta jawaban dari Pak Suripto karena sudah menarik bajunya secara paksa. Tuturan Dilan yaitu, "ada apa pak?" terjadi setelah Pak Suripto menghampiri Dilan dan menarik bajunya. Tuturan tersebut terjadi pada menit 56.55-57.01. 


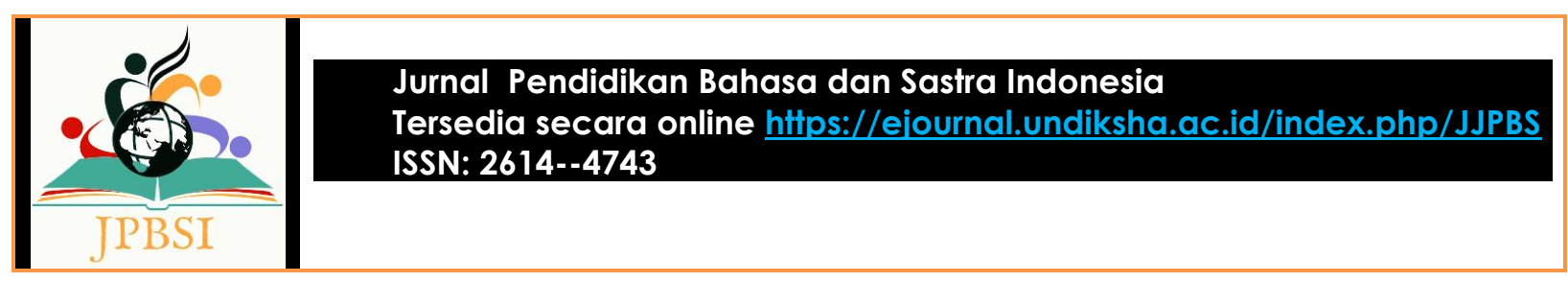

Berdasarkan data tersebut, dapat diketahui bahwa tuturan Dilan dalam kutipan dialog di atas merupakan jenis tindak tutur direktif (menanyakan). Hal ini dilihat pada tuturan Dilan yang menginginkan jawaban atas pertanyaannya kepada Pak Suripto. Bahkan Dilan menegaskan lagi pertanyaannya karena tidak mendapat jawaban dari Pak Suripto. Maksud lain dari tuturan ini adalah Dilan ingin mengetahui maksud Pak Suripto secara tiba-tiba menarik dan mendesaknya keluar lapangan. Tindak tutur yang menunjukkan direktif (menanyakan) ini diketahui dari tuturan tokoh Dilan yang mengucapkan kalimat yang meminta jawaban untuk tujuan atau maksud tertentu.

c. Tindak Tutur Komisif

Pada ilokusi ini, penutur terikat untuk melaksanakan apa yang disebutkan pada penuturnya. Adapun yang termasuk dalam jenis tindak tutur komisif dalam dialog tokoh Dilan pada film Dilan 1990 yaitu, menjanjikan dan menawarkan. Sebagaimana terlihat pada tuturan di bawah ini.

1) Menjanjikan

Dilan : "nanti malem aku mau ke rumahmu"

Milea : "jangan, ayahku galak.” (Baiq dan Bustomi, 2018)

Tuturan (8) di atas merupakan dialog antara Dilan dan Milea. Tuturan tersebut terjadi di gerbang sekolah saat siang hari. Pada tuturan tersebut, Dilan menjanjikan suatu hal kepada Milea atas apa yang disampaikan mengenai rencananya ke rumah Milea malam hari. Tuturan Dilan yaitu, "nanti malem aku mau ke rumahmu" terjadi setelah Dilan menghampiri Milea yang sedang jalan sendirian di gerbang sekolah. Tuturan tersebut terjadi pada menit 14.45-14.48.

Berdasarkan data di atas, dapat diketahui bahwa tuturan Dilan dalam kutipan dialog di atas merupakan jenis tindak tutur komisif (menjanjikan). Maksud tuturan tersebut adalah Dilan menjanjikan suatu hal atas apa yang disampaikannya kepada Milea. Maksud lain dari tuturan ini adalah Dilan memberi tahu Milea bahwa nanti malam akan ke rumahnya dan tuturan tersebut bukan hanya sekedar disampaikan tetapi Dilan benar-benar akan ke rumahnya. Tindak tutur yang menunjukkan komisif (menjanjikan) ini diketahui dari tuturan tokoh Dilan yang menyanggupi dan mentaati ucapannya kepada Milea untuk tujuan atau maksud tertentu.

2) Menawarkan

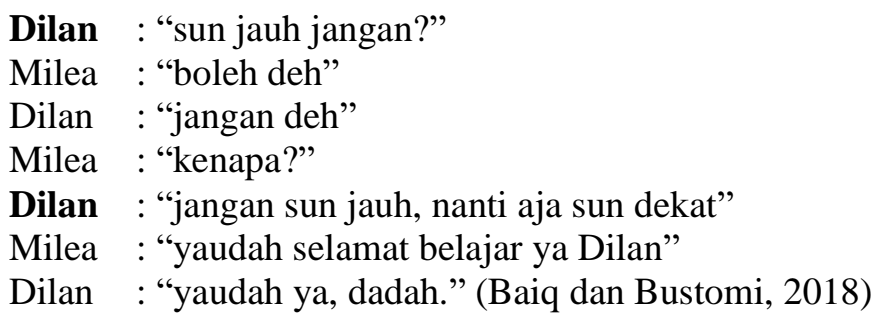

Tuturan (9) di atas merupakan dialog antara Dilan dan Milea. Tuturan tersebut terjadi di saluran telepon saat siang hari. Pada tuturan tersebut, Dilan mengajukan sesuatu yang mengaitkan tuturannya dengan tawaran yaitu tidak usah mencium jarak jauh tapi nanti saja secara tatap muka. Tuturan Dilan yaitu, 'sun jauh jangan?' dan dilanjut “jangan sun jauh, nanti aja sun dekat" terjadi setelah Dilan asyik mengobrol di saluran telepon dan bertanya untuk menawarkan sesuatu. Tuturan tersebut terjadi pada menit 45.20-45.35.

Berdasarkan data di atas, dapat diketahui bahwa tuturan Dilan dalam kutipan dialog di atas merupakan jenis tindak tutur komisif (menawarkann). Maksud dari tuturan tersebut adalah Dilan mengajukan suatu hal untuk ditawarkan kepada Milea. Maksud lain dari tuturan ini adalah ingin bertemu dengan Milea dan tidak hanya mengucapkan saja tetapi akan membuktikan ucapannya. Tindak 


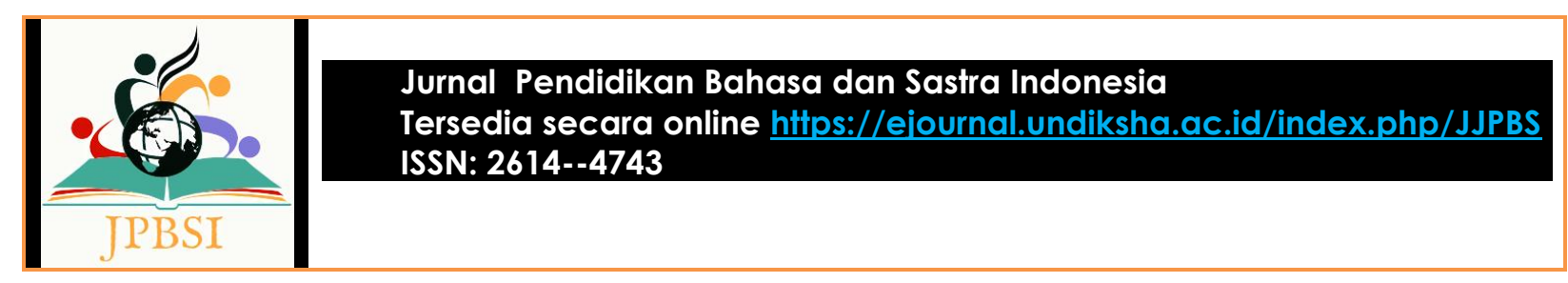

tutur yang menunjukkan komisif (menawarkan) ini diketahui dari tuturan tokoh Dilan yang menyanggupi dan mentaati ucapannya kepada Milea untuk tujuan atau maksud tertentu.

\section{d. Tindak Tutur Deklaratif}

Pada ilokusi ini, penutur menciptakan hal, status atau keadaan yang baru. Adapun yang termasuk dalam jenis tindak tutur deklaratif dalam tuturan tokoh Dilan pada film Dilan 1990 yaitu membuat keputusan. Sebagaimaa terlihat pada dialog di bawah ini.

1) Membuat Keputusan

Dilan : "proklamasi, hari ini di Bandung tanggal 22 Desember 1990 Dilan dan Milea dengan penuh perasaan dengan resmi berpacaran. Hal-hal mengenai penyempurnaan dan kemesraan akan diselenggarakan dalam tempo yang selama-lamanya."

Milea : *tersenyum. (Baiq dan Bustomi, 2018)

Tuturan (10) di atas merupakan dialog antara Dilan dan Milea. Tuturan tersebut terjadi di warung Bi Eem saat siang hari. Pada tuturan tersebut, Dilan membuat keteapan atas status hubungannya dengan Milea. Tuturan Dilan yaitu, "hari ini di Bandung tanggal 22 Desember 1990 Dilan dan Milea dengan penuh perasaan dengan resmi berpacaran" terjadi setelah Dilan meminta Milea membacakan tulisan Dilan. Tuturan tersebut terjadi pada menit 100.48-101.09.

Berdasarkan di atas, dapat diketahui bahwa tuturan Dilan dalam kutipan dialog di atas merupakan jenis tindak tutur deklaratif (membuat keputusan). Maksud dari tuturan tersebut adalah tuturan Dilan mengubah status hubungannya dengan Milea lalu ditetapkan. Maksud lain dari tuturan ini adalah Dilan membuktikan tutura sebelumnya yang akan menjadikan Milea pacar dan Dilan benarbenar mengubah statusnya. Tindak tutur yang menunjukkan deklaratif (membuat keputusan) ini diketahui dari tuturan tokoh Dilan yang membuat ketetapan untuk tujuan atau maksud tertentu.

\section{e. Tindak Tutur Ekspresif}

Pada ilokusi ini, penutur mengekspresikan, mengungkapkan atau memberitahukan sikap psikologisnya terhadap keadaan yang tersirat dalam ilokusi. Adapun yang termasuk dalam jenis tindak tutur ekspresif dalam dialog tokoh Dilan pada film Dilan 1990 yaitu ucapan selamat, ucapan terima kasih, ucapan mengkritik, ucapan mengeluh, ucapan meminta maaf dan ucapan menyanjung. Sebagaimana terlihat pada dialog di bawah ini.

1) Ucapan Selamat

Dilan : "selamat pagi"

Milea : "pagi" (Baiq dan Bustomi, 2018)

Tuturan (11) di atas merupakan dialog antara Dilan dan Milea. Tuturan tersebut terjadi di sekolah saat pagi hari. Pada tuturan tersebut, Dilan memberikan selamat untuk penyambutan pagi hari kepada Milea. Tuturan Dilan yaitu, "selamat pagi" terjadi setelah Dilan menghampiri Milea yang sedang jalan sendirian menuju ruang kelasnya. Tuturan tersebut terjadi pada menit 01.09-01.11.

Berdasarkan data di atas, dapat diketahui bahwa tuturan Dilan dalam kutipan dialog di atas merupakan jenis tindak tutur ekspresif (ucapan selamat). Maksud dari tuturan tersebut adalah Dilan memberikan selamat untuk penyambutan pagi hari dengan rasa senang. Maksud lain dari tuturan ini adalah Dilan ingin menyapa Milea dengan perasaan senang sehingga Milea bisa memberikan respon yang baik untuknya. Tindak tutur yang menunjukkan ekspresif (ucapan selamat) ini diketahui dari tuturan tokoh Dilan yang memberikan ucapan selamat untuk maksud dan tujuan tertentu.

2) Ucapan Terima Kasih 


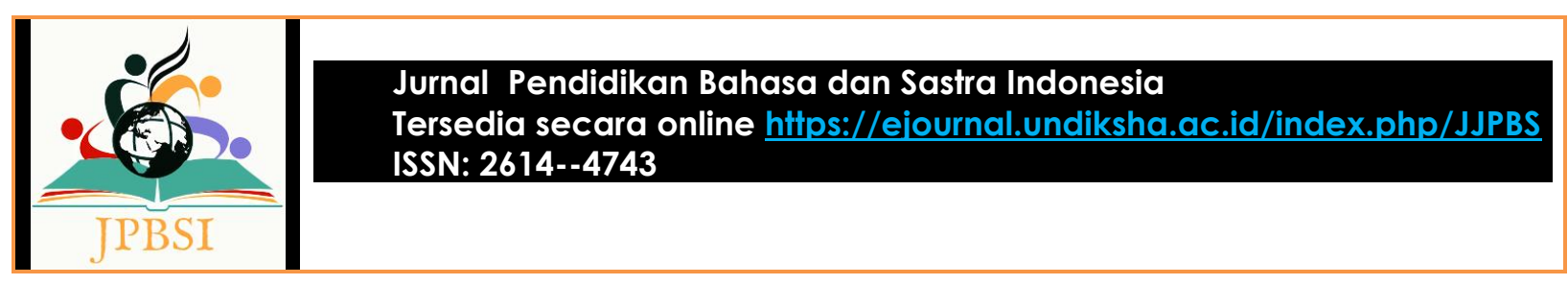

Dilan : "makasih pak"

Bapak Guru : "aduh, iya iya." (Baiq dan Bustomi, 2018)

Tuturan (12) di atas merupakan dialog antara Dilan dan Bapak Guru. Tuturan tersebut terjadi di ruang kelas saat pagi hari. Pada tuturan tersebut, Dilan memberikan ucapan terima kasih kepada Bapak Guru karena sudah diberi izin masuk ke kelas Milea. Tuturan Dilan yaitu, "makasih pak" terjadi ketika Dilan sudah memberikan hadiah kepada Milea. Tuturan tersebut terjadi pada menit 23.49-23.52.

Berdasarkan data di atas, dapat diketahui bahwa tuturan Dilan dalam kutipan dialog di atas merupakan jenis tindak tutur ekspresif (ucapan terima kasih). Maksud dari tuturan tersebut adalah Dilan memberikan ucapan terima kasih kepada Bapak Guru. Maksud lain dari tuturan ini adalah Dilan mengutarakan rasa senang dan syukur karena Bapak Guru yang sudah memberikan izin Dilan masuk ke kelas Milea. Tindak tutur yang menunjukkan ekspresif (ucapan terima kasih) ini diketahui dari tuturan tokoh Dilan yang memberikan ucapan terima kasih atas rasa syukur untuk maksud dan tujuan tertentu.

3) Ucapan Mengkritik

Dilan : "dia narik baju saya pak, kaya gak ada cara lain aja. Dia juga nampar saya"

Kep. Sekolah : "ya mungkin pak Suripto punya maksud"

Dilan : "pak, guru itu digugu dan ditiru. Kalo Suripto berani menampar muridnya Pak, kami sebagai murid juga berhak menampar balik Pak." (Baiq dan Bustomi, 2018)

Tuturan (13) di atas merupakan dialog antara Dilan dan Kepala Sekolah. Tuturan tersebut terjadi di ruang kepala sekolah saat pagi hari. Pada tuturan tersebut, Dilan memberikan kritik karena Kepala Sekolah malah meminta memaklumi perlakuan Pak Suripto yang sudah menarik paksa baju Dilan saat pelaksanaan upacara. Tuturan Dilan yaitu, "pak, guru itu digugu dan ditiru. Kalo Suripto berani menampar muridnya Pak, kami sebagai murid juga berhak menampar balik Pak" terjadi setelah Kepala Sekolah menanyakan yang terjadi di lapangan. Tuturan tersebut terjadi pada menit 58.25-58.48.

Berdasarkan data di atas, dapat diketahui bahwa tuturan Dilan dalam kutipan dialog di atas merupakan jenis tindak tutur ekspresif (ucapan mengkritik). Maksud dari tuturan tersebut adalah Dilan memberikan kritik atas perlakuan Pak Suripto yang disampaikan kepada Kepala Sekolah. Maksud lain dari tuturan ini adalah Dilan meluapkan emosinya karena tidak terima atas perlakuan Pak Suripto. Tindak tutur yang menunjukkan ekspresif (ucapan mengkritik) ini diketahui dari tuturan tokoh Dilan yang mengemukakan kritik dan kecaman untuk maksud dan tujuan tertentu.

4) Ucapan Mengeluh

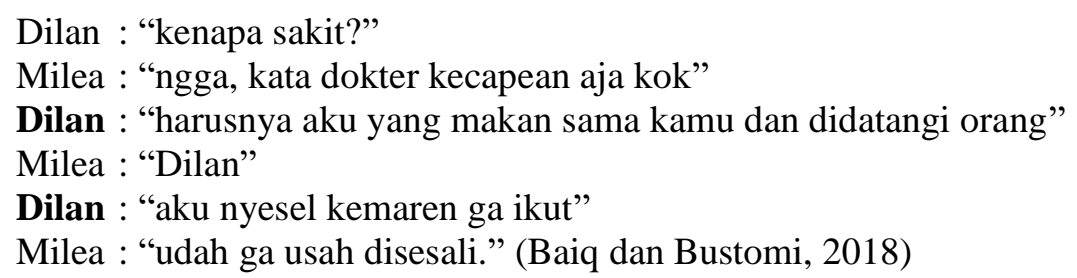

Tuturan (14) di atas merupakan dialog antara Dilan dan Milea. Tuturan tersebut terjadi di saluran telepon saat sore hari. Pada tuturan tersebut, Dilan mengutarakan rasa kecewa terhadap dirinya sendiri. Tuturan Dilan yaitu, "harusnya aku yang makan sama kamu dan didatengi orang" dilanjut "aku nyesel kemaren ga ikut" terjadi setelah Dilan mengetahui kabar bahwa Milea sakit. Tuturan tersebut terjadi pada 37.51-38-08. 


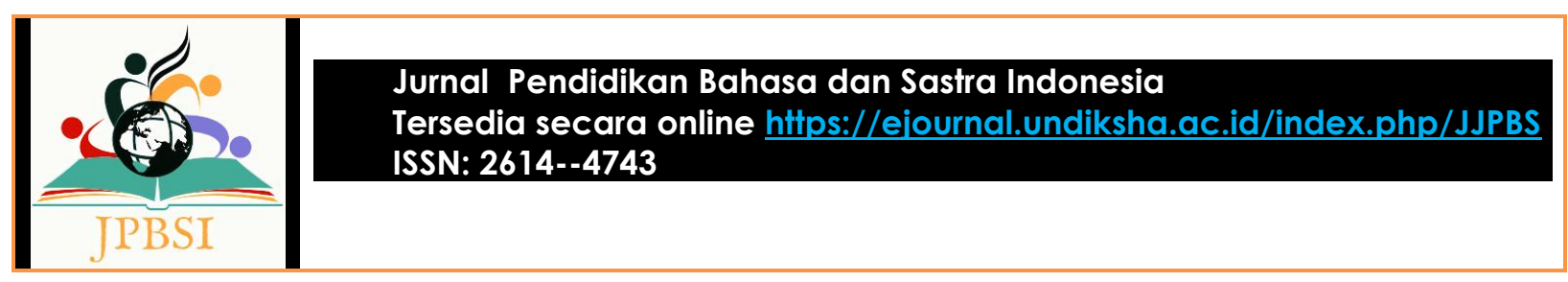

Berdasarkan data di atas, dapat diketahui bahwa tuturan Dilan dalam kutipan dialog di atas merupakan jenis tindak tutur ekspresif (ucapan mengeluh). Maksud dari tuturan tersebut adalah Dilan mengutarakan kekecewaannya pada diri sendiri. Maksud lain dari tuturan ini adalah Dilan merasa kesal dan gagal untuk menjaga Milea sehingga ingin Kembali ke waktu Milea didatangi kekasihnya di Jakarta. Tindak tutur yang menunjukkan ekspresif (ucapan mengeluh) ini diketahui dari tuturan tokoh Dilan yang menyatakan susah hingga kecewa untuk maksud dan tujuan tertentu.

5) Ucapan Meminta Maaf

Dilan : "maaf kalau aku mengganggumu"

Milea : "tuh angkotmu." (Baiq dan Bustomi, 2018)

Tuturan (15) di atas merupakan dialog antara Dilan dan Milea. Tuturan tersebut terjadi di depan rumah Milea siang hari. Pada tuturan tersebut, Dilan mengharap diberi maaf karena takut Milea merasa risih atas perlakuannya. Tuturan Dilan yaitu, "maaf kalau aku mengganggumu" terjadi setelah Milea memberi tahu ada angkot untuk meminta Dilan pergi. Tuturan tersebut terjadi pada 08.37-08.39.

Berdasarkan data di atas, dapat diketahui bahwa tuturan Dilan dalam kutipan dialog di atas merupakan jenis tindak tutur ekspresif (ucapan meminta maaf). Maksud dari tuturan tersebut adalah Dilan mengutarakan rasa bersalah dan mengharap diberi maaf Milea. Maksud lain dari tuturan ini adalah Dilan menjaga kedekatannya dengan permohonan maaf. Tindak tutur yang menunjukkan ekspresif (ucapan meminta maaf) ini diketahui dari tuturan tokoh Dilan yang mengharap diberi maaf untuk maksud dan tujuan tertentu.

6) Ucapan Menyanjung

Dilan : "ini hari pertamaku duduk denganmu. Milea, kamu cantik."

Milea : "makasih"

Dilan : "tapi aku belum mencintaimu, ga tau kalua sore. Tunggu aja." (Baiq dan Bustomi, 2018)

Tuturan (16) di atas merupakan dialog antara Dilan dan Milea. Tuturan tersebut terjadi di mobil angkutan umum saat siang hari. Pada tuturan tersebut, Dilan mengutarakan rasa kagum karena pertama kalinya bertemu dan melihat wajah Milea yang cantik. Tuturan Dilan yaitu, "ini hari pertamaku duduk denganmu. Milea, kamu cantik." terjadi setelah Dilan ikut pulang bersama Milea menaiki angkutan umum. Tuturan tersebut terjadi pada 07.31-07.44.

Berdasarkan data di atas, dapat diketahui bahwa tuturan Dilan dalam kutipan dialog di atas merupakan jenis tindak tutur ekspresif (ucapan menyanjung). Maksud dari tuturan tersebut adalah Dilan mengutarakan rasa kagum atas kecantikan Milea. Maksud lain dari tuturan ini adalah Dilan ingin mendekati Milea dan memujinya agar Milea merasa senang. Tindak tutur yang menunjukkan ekspresif (ucapan menyanjung) ini diketahui dari tuturan tokoh Dilan yang menyatakan rasa kagum untuk maksud dan tujuan tertentu.

\section{PENUTUP}

Jenis tindak tutur ilokusi yang ditemukan dalam dialog tokoh Dilan pada film Dilan 1990 karya Pidi Baiq dan Fajar Bustomi adalah tindak tutur asertif, direktif, komisif, deklaratif dan ekspresif. Tindak tutur asertif yang ditemukan dalam film ini terjadi pada tuturan yang mengikat penutur akan kebenaran informasi yang diutarakan seperti tuturan untuk menyatakan, memberitahukan, melaporkan dan menegaskan kepada mitra tutur. Tindak tutur direktif yang ditemukan dalam film Dilan 1990 terjadi pada tuturan penutur agar mitra tutur melakukan sesuatu yang diinginkan oleh penutur seperti tuturan memerintah, menyarankan, memohon dan bertanya. Tindak tutur komisif yang ditemukan dalam film Dilan 1990 terjadi pada tuturan yang mengikat penuturnya untuk melaksanakan yang disebutkan dalam 


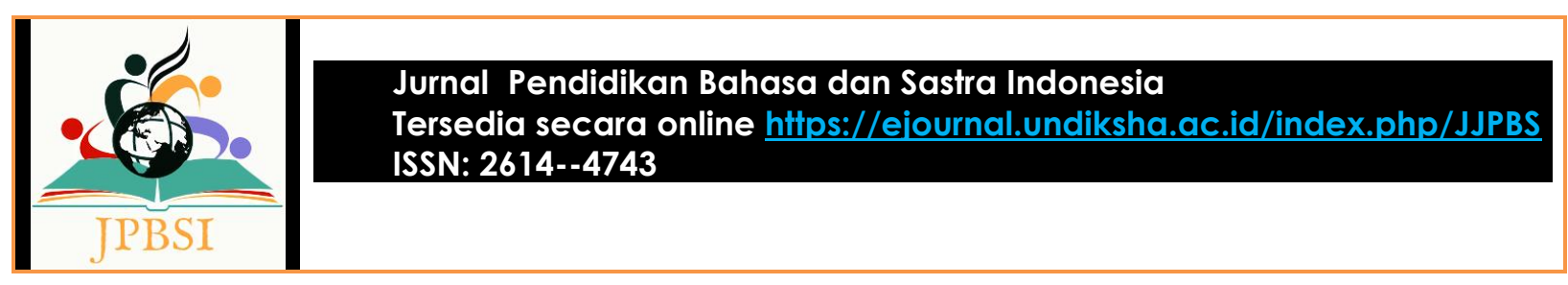

tuturannya seperti menjanjikan dan menawarkan. Tindak tutur deklaratif yang ditemukan dalam film Dilan 1990 terjadi pada tuturan penutur yang menciptakan hal baru seperti memberi nama dan membuat keputusan. Tindak tutur ekspresif yang ditemukan dalam film Dilan 1990 terjadi pada tuturan penutur untuk mengekspresikan sesuatu atau mengutarakan perasaan psikologis kepada mitra tutur seperti tuturan untuk mengucapkan selamat, terima kasih, mengkritik, mengeluh, meminta maaf dan menyanjung.

\section{DAFTAR PUSTAKA}

Agutiani, Tanti. (2019). Studi Wacana. Sukabumi: Okeprint

Khairina, Adinda Ayu. (2017). "Tindak Tutur Ilokusi dalam Dialog Film "Aku, Kau, dan KUA" Karya Monty Tiwa”. Jurnal Sastra Indonesia Universitas Diponegoro. (1-14).

Kusumaningsih, A. Indah. (2016). Tindak Tutur Ilokusi Dalam Film Hors De Prix Karya Pierre Salvadori. Skripsi Sarjana pada FBS UNY Yogyakarta: E-Print UNY

Purba, Andiopenta. (2011). Tindak Tutur Dan Peristiwa Tutur. Jurnal Pena. 1/1 (77-91).

Rusminto. (2015). Analisis Wacana Kajian Teoritis Dan Praktis. Yogyakarta: Graha Ilmu.

Setyanto, Bowo. (2015). Tindak Tutur Ilokusi Dialog Film 5 Cm Karya Rizal Mantovani ( Sebuah

Tinjauan Pragmatik). Jurnal Pendidikan Bahasa Sastra Indonesia dan Daerah. (2).

Sugiyono. (2018). Metode Penelitian Pendidikan Pendekatan Kuantitatif, Kualitatif Dan R Dan D. Bandung: Alfabeta.

Suryanti. (2020). Pragmatik. Klaten: Lakeisha.

Sutedi. (2011). 3 Metode Penelitian Hukum. Jakarta: Sinar Grafika

Tarigan, Henry Guntur. (2015). Pengajaran Pragmatik. Bandung: Penerbit Angkasa.

Yule, George. (1996) Pragmatics. In IF. Wahyuni (Ed). Pragmatik. (2014) Cetakan ke II . Yogyakarta: Pustaka Pelajar.

Copyright holder: @ Rohmah, S. N. M., Firdaus, A. \& Setiadi, D. (2021)

Fist publication right: Jurnal Pendidikan Bahasa dan Sastra Indonesia Undiksha

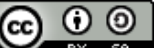

